\title{
Ilarie Voronca and the Romanian Literary Avant-Garde
}

Ion Pop

Ilarie Voronca (born Eduard Marcus, 1903-1946) occupies a central position in the history of the Romanian literary avant-garde during the nineteen twenties and thirties. Born into a middle class Jewish family (his father was a merchant) in Brăila, in the south of the Moldovian region of Romania near the Danube, he studied in Bucharest during his high school and college years, earning a law degree in 1924, then continued his education in Paris, where he also visited frequently. He returned to Bucharest in 1929 to work in the press corps of the Ministry of Foreign Affairs, but was fired in 1931 for racial reasons. By 1933, having moved to Paris, he adopted French definitively in his writings, and published numerous volumes of prose poems as well as more traditional poetry. During the Nazi Occupation, he had ties to the Resistance in the South of France. After the war, as the person in charge of the Radio France Romanian broadcasts, he was warmly received in Bucharest during a visit in January 1946. But soon after his return to Paris, on 5 April 1946, he committed suicide, bringing to an end a dramatic love affair.

Voronca's literary maturation took place in the "modernist" intellectual milieu that crystallized around the journal Sburătorul (The Sylph). His first poems appeared in this journal in 1922, at a time when symbolism's last echoes were dimming. His earliest literary model was the poetry of George Bacovia (18811957), the most important of the Romanian "decadent" symbolists, but soon Voronca was drawn to the new avant-garde currents that started appearing in the circles associated with the journal Contimporanul (The Contemporary, 1922-1932). More to the point, this was the publication that offered - for the first time in Romania - a program of openness toward the radically new literary and artistic movements in Europe. Even though the first futurist manifesto by F. T. Marinetti (1909) had been translated into Romanian a short two weeks after its publication in the Paris journal Le Figaro, local social and literary circles were far from prepared for the total upheaval of values advocated by this manifesto, since Romanian literature was still in search of a modernism attuned to the metamorphoses proposed by the earlier current of French symbolism. This is also the reason why an iconoclastic, radically negating movement like Dada, whose main figure in 1916 was the Romanian Tristan Tzara, could only be launched in an international environment, in Zurich, with barely an echo resonating in the native land of its 
key leader. It was not until the early nineteen twenties, shortly after the Romanian national unification of 1918, in a country ambitious for progress and eager to engage in the dynamic of cultural modernism, that the ideas being propagated in avant-garde circles would bear fruit. The strong emphasis on nation building helps to explain Romania's openness toward "constructivist" movements in the avantgarde. Marcel Iancu (Janco), painter and architect, who had participated with his friend Tzara in the dadaist movement launched at the Cabaret Voltaire, left Dada after being drawn to the constructivist abstractionist ideas of the German Bauhaus and returned to Bucharest where, alongside Ion Vinea, also one of Tzara's friends, he became the chief editor of Contimporanul. Very rapidly, this magazine became the main voice of the Romanian avant-garde urging opposition to stale literary traditions, and it generously welcomed followers of all modernist movements of the time, from Italian and Russian futurism to German and Dutch constructivism, even French surrealism, informing readers about key innovative events from all over Europe. The "Manifest activist către tinerime" (Activist Manifesto addressed to Youth), published in May 1924 by Ion Vinea, polemicized the cultural past; in content and tone, it bore echoes of both constructivism (a reliance on elements of abstract art and on a corresponding literary expression) and futurism, whose revolutionary verve it adopted. Periodicals such as $75 \mathrm{HP}$ (a single issue published in October 1924), Punct (Point, fifteen issues between 1924 and 1925), and Integral (sixteen issues from 1925 to 1928) would be programmatically affiliated, as it were, with Contimporanul. Ilarie Voronca would also be present on another avant-garde scene in Romania: the circles associated with the magazine unu (One, 1928-1932), in whose pages the editor, the poet Saşa Pană, initiated the very first overtures toward surrealism. Other associates of unu were the painter Victor Brauner and the poets Stephan Roll (Gheorghe Dinu) and Geo Bogza.

We can therefore characterize Voronca, who was actively engaged in the early stages of many of the Romanian avant-garde movements, as a poet of "modernist synthesis" because elements typical of each of the avant-garde artistic tendencies can be found in his work. However, soon after his move to Paris, Voronca's work would take another turn: what at first was a luxuriant imagery based on unusual associations became a much more simple and direct discourse, explicitly committed to the "masses of the future," whose forthcoming victory over all current forms of oppression it declared openly. Voronca, therefore, left behind at this point his rebellious militant past, declaring that he no longer found "joie à réunir des mots étranges" ("Les foules de l'Avenir") 'pleasure in inventing bizarre words.'

\section{On Avant-garde Terrain}

Before reaching this later stage, however, Voronca had been one of the most passionate militants and participated in each of the stages of the Romanian avantgarde during what was a relatively short but remarkably rich period. Yet the 
evocative portrait drawn in the memoirs of Eugen Lovinescu, the great literary critic and principal promoter of Romanian modernism, who had published Voronca's first poems in 1929 in Sburătorul, gives us a sense of a fragile personality:

. . suflet timid, nostalgic, sentimental, răvăşiit, descompus, suflet legat de țară, de pământ, inactual, inutil, cu voinţi dizolvate în veleităţi, cu entuziasmuri puerile, gingaş şi pretenţios . . . suflet moldovenesc, adică slav, risipit de vânt ca o scamă de păpădie, suflet de toamnă şi de învins, incapabil de acţiune şi de iniţiativă, suflet de Mărculescu şi nu de Marcus, râvnind să devină funcționar român, cu ore de serviciu fixe. (178-79)

. . . a timid, nostalgic, sentimental soul, scattered, lacking focus, a soul with strong ties to the country, the soil; not of the present, useless, volition dissolved in velleities, filled with childish enthusiasms, fragile and pretentious ... a Moldovian soul, which is to say Slavic, blown about by the wind like the seeds of the dandelion; an autumnal and vulnerable soul, incapable of action or initiative; the soul of a Mărculescu, not of a Marcus, looking only to become a Romanian bureaucrat, with steady work hours.

All the elements of this portrait contradict the pose of "un războinic cu pistoale la brâu" 'a warrior with pistols in his holster,' thus a suspicion of bovarysme emanates from this "contemplativ visător, care vrea să fie revoluţionar" (178-79) 'pensive dreamer who wants to be a revolutionary.'

The volume Restrişti (Sadness) from 1923 in fact shows just such vulnerable sensibilities. In it are poems in the post-symbolist mold, following in the footsteps of George Bacovia's "decadent" crepuscular imagery: the poems tell of the vagaries of a frail wanderer pining under the window of the beloved, roaming along the "cheiuri stinse" 'dark embankments' of the Danube, in the city plunged in darkness, with grey walls, desperate inhabitants, and "femeile cu mâini subţiri şi triste" 'women with thin, sad hands,' finding "mereu viața ca un ceasornic oprit" 'life always like a clock that had stopped,' in a state of fatigue and permanent exhaustion. But these laments of a pale-faced high school boy in search of an escape "dincolo de mâhniri" 'beyond sadness' were delivered by lines charged with bold, original imagery that built unusual equations from disparate elements, harming the whole in some ways, yet ensuring the emergence of a dynamic vision from the stagnant atmosphere.

Voronca's was a rapid poetic evolution given his strong receptivity to the innovations announced by the avant-garde that started to form around Contimporanul. Having begun publishing in this magazine, launched in 1922, he was fast won over by the iconoclastic and revolutionary ideas proclaimed by Vinea's 1924 manifesto, in which he demanded, "Jos Arta, căci s-a prostituat!" 'Down with Art, that prostitute!' to be replaced with "minunea cuvântului nou şi plin în sine, expresia plastică, strictă şi rapidă a aparatelor Morse" "the marvel of the new word that that suffices, in and of itself; a mode of expression like that of 
Morse machines: plastic, strict, and fast.' Vinea was clearly adopting the slogans of European constructivists, but there is, too, the energy inherited from the Italian futurists and a fascination with the dynamism of "the grand industrial activist period" in which Romania was invited by the same token to participate.

The young Voronca could thus be found on the barricades of the new movement, publishing articles and poems also in Punct, "the magazine of the constructivist avant-garde." Adopting a fiery voice in "Aviogramă," published "instead of a manifesto" in $75 \mathrm{HP}$, which he edited with Victor Brauner and Stephan Roll, Voronca proposed a new "grammar" of poetry. Under a bold and radical slogan - "Cetitor, deparazitează-ți creierul” 'Reader, debug your brain' he called for a text written in the manner of "futurist words in freedom," using newspaper clippings borrowed from the Dada toolkit and employing a technical vocabulary of constructivist origin (n. pag.; 535-36). An avalanche of images suggests the bustle of the modern city with its "î[m]părăţia afişelor luminoase" 'kingdom of luminous posters,' "telegraful a țesut curcubee de sârmă" 'the telegraph [that has] wove[n] wire rainbows,' and "colierul de faruri" the 'lighthouse necklace' falling into a rhythm reminiscent of the "Morse machines" of the "Activist Manifesto." In a spectacularly aggressive style, he urges "lepădarea formulelor purgative" 'the denial of purging formulas' and promises, with strong emphasis, that "când formulă va deveni ceeace facem ne vom lepăda şi de noi în aerul anesteziat" "when what we're doing becomes formula we'll deny ourselves, too, in the anesthetized air'! Ironically, the image "gramatica logica şi sentimentalismul ca agăţătoare de rufe" 'grammar logic emotionalism as linen pins' bears remarkable echoes of Tzara's dadaist declaration "la logique est toujours fausse" ("Manifeste 365") 'logic is always false' ("Dada Manifesto" 11) or of Ribemont-Dessaignes' announcement "we shall take a big antiseptic bath." All this is in the provocative style "of a manifesto-magazine meant to provoke the indignation of our elders," as Victor Brauner put it (Brauner interview). In this same journal, under the pen name of Alex. Cernat, Voronca published an article entitled "1924" in which he proclaims, using similar imagery, "triumful cerebralității music-hallului acrobatismului elegant politicos până la gazometru" 'the triumph of music hall's cerebrality [and of] an elegant acrobatism polite up to the gasometer,' and he notes that "cuvintele cu intestinele despletite aleargă prin foburg înlănţuindu-se în jazzul frazelor vertiginoase" "words with disheveled bowels run through the faubourg wrapping themselves in the jazz of vertiginous sentences' and exalts " INVENȚIA INVENȚIA INVENȚIA. . . . eră de INTELIGENȚA $\breve{A}$ VITEZĂ de INTELIGENȚA $\breve{A}$ cu 60 de etaje ascensor” ‘INVENTION INVENTION INVENTION. . . . an era of INTELLIGENCE SPEED OF INTELLIGENCE with 60 floors elevator ("1924"; “Untitled Statement"). And he does not fail to mention that most recent invention, PICTOPOETRY, as "a synthesis of the new art," launched by Victor Brauner on a different page of $75 \mathrm{HP}$, placed under an illustrative literary-artistic collage. Pictopoetry is defined jocularly: "Pictopoezia nu e pictură. Pictopoezia nu e poezie. Pictopoezia e 
pictopoezie" 'Pictopoetry is not painting. Pictopoetry is not poetry. Pictopoetry is pictopoetry.' Beyond the obvious playfulness one can detect the abstract constructivist requirement that painting and text be read literally, with no pretense of seeing in it a naturalistic representation of a figure outside the given compositional space.

As for Voronca's poetry in $75 \mathrm{HP}$, it consists, true to the stated program, of texts filled with technical terms, laid out on the page in the futuristic manner, using black and red letters, immediately adjacent to two parodizing "stanzas," one being the mirror reproduction of the other. For those who want "to collaborate on 75 $H P$," conditions are posed-in French, and always ironically-, bearing the hallmark of Dada influences: "savoir bien danser / uriner sur tout / respecter ses parents / avoir souffert un accident d'avion / ne pas faire de la littérature / avoir un certificat de bonne conduite" 'be a good dancer / urinate on everything / honor one's parents / have experienced an airplane crash / create no literature / earn a certificate of good behavior.' On another page, another accomplice, Mihail Cosma, the future Claude Sernet, writes in turn: "Littérature - le meilleur papier hygiénique du siècle " 'literature - the best toilet paper of the century.'

\section{Voronca and the "New Poetry"}

At the same time that he was thus playfully borrowing from the style of Dada's revolt and the constructivists' arsenal, Voronca was also proposing, in his articles in Punct, important innovations intended to lead to a "new poetry." Certainly his concept of poetry was formed by the constructivist program launched on the pages of Contimporanul, and his model for literary discourse is that of abstract art:

Cuvântul în literatură ca şi culoarea sau linia în pictură are un rost abstract, mai presus de înţelesul gramatical sau logic. Există o chimie a cuvintelor cu interesante rezultate ale acțiunilor dintre ele. Verbul, întrebuințat pur, asemeni materialelor din construcțiile plastice, capătă o semnificație neînregistrată de dicţionar. . . . Artistul adevărat creează direct, fără simbol, în pământ, lemn sau verb, organisme vii, maşini spintecând drumuri, strigăte tresărind violent ca în furtună acoperişuri. Cuvintele obţin astfel propriul lor sens, boxând sau îmbrăţişându-se între ele. . . . Fraza nu mai e o ficţiune amintind discursul electoral sau declaraţia de dragoste sub lună a plăcintarului devenit brusc poet. ("Gramatică")

The word in literature, similarly to color or line in painting, has an abstract role more important than grammatical or logical meaning. There is a chemistry of words, and interesting results come from their interaction with each other. The verb when used purely, just as the materials used in visual structures, gains a meaning not registered in the dictionary. ... The true artist creates directly, without symbols, be it in 
wood, earth, or verb, making living organisms, cars cutting through roads, cries erupting violently just like roofs in a storm. Words thus gain their own meaning, either fighting or embracing each other. . . . The sentence is no longer a fiction reminiscent of electoral discourse or of the moonlit love declarations of a pie maker turned suddenly poet.

We can easily recognize here a definition of the "concrete poetry" based on futurist and Dada foundations, extolled by European constructivists such as Theo van Doesburg from the Dutch group De Stijl, or by Kurt Schwitters, and even by Tzara in his brief period of sympathy for abstract art. A whole tradition of modernist poetry that denies anecdote and conceptual discourse is reflected here. Of course, the typical rhetoric of all avant-garde manifestoes can be gleaned in these sentences, which exalt "the innovating effort" over the rules established by an ossified grammar. An echo of the sportsmanlike energy of the futurists, lovers of achievement, also permeates these lines: “Creatorul adevărat şi nou sfărâmă cu târnăcopul temperamentului său legile cunoscute. Orice artist trebuie să fie aducătorul unor alte principii, scoborând în concertul de fulgere de pe muntele Sinai cu tablele logicei noi în mâini" "The true and new creator smashes familiar laws with the pickaxe of his temperament. Any artist must be the bringer of new principles, descending in the concert of thunder from Mount Sinai with the tablets of a new logic in his hands.' Hence the incitation to reverse the call of the wellknown nineteenth century Romanian Romantic author, Ion Heliade: "Scrieți, băieți” 'Write, boys,' which "trebuie reeditat deci, săpând în el semnificația vremii: 'Faceți greşeli de gramatică'”" 'will have to be edited by sowing into it today's significance: "Make grammatical errors."'

Like all avant-garde authors, Ilarie Voronca shows himself to be conscious of the hold that the present, "the rhythm of our times," has over the process of creation, and he notes the foreshadowing character of certain poetic experiences, underlining the separation between art and logic. As Tzara did earlier, he affirms that "Artistul nu se interesează niciodată de gradul comprehensibil al operei sale. ... Gustul, ochiul, urechea spectatorului trebuiesc neîncetat violate. Opera de artă trăieşte numai prin ignorarea tuturor regulilor cunoscute" ("Glasuri") 'The artist is never interested in the degree of comprehensibility of his work. . . . The taste, eyes, ears of the spectator must be continually violated. The work of art lives only through its disobedience of all known rules.' This maximalist viewpoint is characteristic of the degree of commitment to radical innovation by the avantgarde.

Another idea close to the heart of the poet is the creation, in art as well as literature, of a process of "synthesis": "Poezia, plastica, drama, muzica şi mai ales arhitectura, toate converg într-un acord abstract, pe acelaşi drum arcuit ca o coardă: sinteza. Astăzi realizările de artă sintetică, poezie, construcție, vestesc tumultuos, viril, SECOLUL-SINTEZĂ" ("Glasuri”) 'Poetry, the visual arts, theater, music, and most of all architecture - all converge into an abstract accord, following the same path tensed like an arc: synthesis. Today the products of 
synthetic art, poetry, architecture all foretell - tumultuously and with virility THE SYNTHESIS-CENTURY.' This idea will be frequently found in Voronca's statements appearing in Integral, which, starting in March 1925, began to take over from Punct. The exclusivist point of view underlying the constructivist program will disappear on this new, more open artistic stage, its creators declaring their receptiveness to everything new emerging in both contemporary literature and the arts. Along with Mihail Cosma, who presented the "integrative" phase of the Romanian avant-garde as proof of a new openness toward the "accomplishments" of the era, Voronca was the most militant figure committed to the new ideal. Surveying all the important modernist movements, Cosma wrote in that journal that one had to leave behind unilateral perspectives on the world and undertake the action of uniting all forces of the time: "Timpul naiv al experientei unilaterale a trecut. Vrem înfăptuiri integrale" "The time for naïve unilateral experiments has passed. We want to forge integral accomplishments.'

This is, for all intents and purposes, the same way of seeing things, and Voronca will continue to develop ideas that lead to similar conclusions. Writing about the relationship between constructivism and surrealism, he initially rejected the movement led by André Breton, suggesting that, compared to the formal rigor of the former, the latter erred by indulging in too much disorder, adopting “dezagregarea bolnavă, romantică" 'a sick, Romantic disintegration,' and proposing creative solutions that were already obsolete. Gradually, Voronca would revise these cutting judgments and, while maintaining his emphasis on constructivist ideas, would shift his focus to the necessity of understanding the bigger picture of contemporary cultural phenomena:

[T]ăria însăşi a curentului actual consistă în integralul tuturor eforturilor de pretutindeni ; filon unitar, nerv vibrând acelaşi în plastică, literatură, muzică, arhitectură, teatru. Există, neîndoielnic, o intensă analogie, mai presusu de trăsăturile înnăscut organice. O analogie-esență, o analogie de corpuri geometrice. . . . Substanța poeziei noi - am spus - a rămas aceeaşi. Observarea ei e însă cu totul alta: ştiinţifică, nu ca precizie, ci ca sistem: organică, obiectivă. Poetul drumului de azi nu geme, nu se emoţionează bolnav, nu-şi şterge lacrimile de carnea uneori pietroasă a fluviilor. Aspru, sub biciul lui turma stelelor latră sălbatic. . . . [P]oezia devine dintr-odată universal umană, poezia-poezie, poezia-ciment, poeziaplanşă de inginer, organism viu, integrat simplu între fenomenele naturale. ("Cicatrizări")

The very strength of the current movement resides in the integration of all efforts from all quarters; a single vein, one nerve is vibrating through the plastic arts, literature, music, architecture, theater. Undoubtedly, there is one intense analogy that supersedes all innate organic traits. This is an essential analogy, an analogy of geometric bodies. ... The substance of new poetry - I said - has remained the same. But the way of observing 
it is an entirely different matter altogether: scientific, not in precision, but as a system: organic, objective. The poet on today's journey does not groan, does not show sickly emotion, does not wipe his tears of the sometimes rocky flesh of rivers. He is tough; under his whip the flock of stars barks wildly. . . . poetry suddenly becomes universally human, poem-poem, poem-cement, poem-blueprint, a live organism, simply integrated into nature.

The tone of his discourse maintains the high pitch of carefully administered rhetorical effects:

Expresia poetului nou e plină de cutezare, de savoare absurdă: târnăcop, bumerang, salt întrecând în înălțimne toate performanțele mondiale. . . . Poemul țipă, vibrează, dizolvă, umbreşte, zgârie, înspăimântă sau calmează. Imaginile se îmbulzesc nu în comparații sterpe, ci în asociaţii fulgere, frunziş în noapte. Orice vers e o sumă de noi posibilităţi, o altă soluţie a ecuaţiei primare.

The means of expression of the new poet is full of daring, of absurd flavor: it is a pickaxe, a boomerang, a leap higher than any world record. .. . The poem shrieks, vibrates, dissolves, shadows, grates, scares or calms. Images jostle each other not as barren similes, but thunder-fast associations, leaves in the night. Any verse is a sum of new possibilities, a different solution to the original equation.

The reader does not need extended explanations to (re)discover [here] a release of energy reminiscent of the futurists, the same language of performance, a lived tension through which the poet aims to reconcile extreme states: a direct, almost carnal, grasp of reality and a geometric austerity in articulating the images of the world in a filtered, essentializing mode of expression that is also multivalent and reverberative. Voronca thus offers a kind of expressive concentrate of this "modern synthesis" characteristic of the first period of the Romanian avant-garde, whose practitioners felt almost obliged by forces of historical circumstance to find, while forging their identity, ways to recover the stages skipped during their modern evolution. It is interesting in this regard to note the definition Voronca gives of the poetic image in an article he writes about the great modernist poet Tudor Arghezi: "plăsmuire abstractă, imaginea: raport pur, a două elemente cât mai depărtate (sau cât mai apropiate) între ele" ("Tudor Arghezi") 'abstract creation, the image is a pure relationship of two elements that are the farthest (or closest) possible from one another.' At first, this definition appears to be similar to the abstractionist vision of the constructivists, but in its overall outline it also resonates with Marinetti's reflections on this topic, while at the same time coming closer to Breton's definition, built on the formulations of Pierre Reverdy. The notion of "lightning-fast associations" is an eloquent case in point, and to these 
associations Voronca will soon return, when he confesses more or less directly his sympathies with surrealism, despite having denied them so very clearly earlier on.

Voronca's poems in this constructivist-integralist period embody underlying programmatic requirements. Such a poem is Signalisations (Signals), which, using the technical language of "the engineer in front of his blueprints," develops a series of rapid notations that let themselves be carried on the random waves of a futuristlike imagination or by a type of fortuitous association characteristic of Dada. But in general, this poetry of "impressionist" notations presents a certain geometrically stylized landscape, where moods are associated with technical objects or daily news stories, and the tone is akin to journalism's rapid, terse manner: "Orice pasăre un afiş ceresc" 'Any bird a celestial poster'; “Cheamă glasul în moloz: VA URMA" "The voice in the debris is calling: TO BE CONTINUED'; "Catalog de maşini agricole: Sena" 'Catalogue of agricultural equipment: the Seine'; “Ce cale ferată arterele tale cu sânge şi gări !” ‘What train tracks are your arteries, full of blood and railway stations!'; "Părul tău a spălat atât de chimic orele" 'Your hair washed the hours so chemically'; "Ce tipografii ochii tăi / Şi pupilele tale rotative imense / Cum se desfăşoară din privirile tale / Toată viaţa mea / Ca un jurnal cu ultimele ştiri” 'What printing presses your eyes are / And your pupils like immense cylinders / How my entire life / Rolls off from your gaze / Like a paper with the latest news.' In general, this poetry is dependent on vision, on the eye curious about everything happening around it; a poetry that displays, exposes, and registers various objects: shop windows, catalogues, calendars, wardrobes, collections, panoplies, registers, albums. The perspective is kaleidoscopic; panoramas open up under the astonished gaze of the spectator of modern life. The new "grammar" of poetry thus brings an important contribution to the lyrical lexicon, at times shocking to traditional sensibilities, as all conventions are overturned by these bizarre associations.

Yet the major works of Voronca in this period are the long poems Ulise (Ulysses, 1928), Bratara noptilor (The Nights' Bracelet, 1929), Zodiac (1930), and Petre Schlemihl (1932; the Romanian version of the name of the famous wandering hero of German literature). Ulise, a "hymn dedicated to the century of mediocrity," is a spectacular "lyrical reportage" structured in a "cubist" or "simultaneous" manner, focusing on modern urban life with the Parisian metropolis at its core. It is a work of exceptional imagination, poetic energy, and associative power that appears inexhaustible in its inventions, reminiscent of baroque profusion in its stunning assemblages of facts and objects built with a dexterity akin to mannerism's refined ingenuity. It is Ulise that earned Ilarie Voronca the title of "billionaire of images" from Eugen Lovinescu, the same critic who launched his literary career. Granted, he has been criticized for a certain excess, a type of inertia manifested in the flow of a barely controlled discourse, and for all too easily slipping into an explosive and quite flamboyant fantasy world. The European models to which one might compare these poems are Apollinaire's Zone, or the "whole world" poems of Blaise Cendrars, Valéry Larbaud, or Paul Morand, all of whom created, fundamentally, 
amply Whitmanesque discourse. What sets the Romanian poet apart is his overflowing imagery, while Apollinaire, for example, was inclined rather to depoeticize his view of "this ancient world" of which he declared himself "tired." The topos of the magical city with its illuminated billboards and colorful streets and crowds returns again and again in Voronca's verses, which suggest a particularly urban type of dynamism, rich with bold images. There is, however, also a presence of more natural elements such as the vegetables in the farmer's market, or "hymns" to tea or the potato, which causes a shift in the poetic mood as well as in the text itself from "reporting" to careful prosody, rhymes, and rhythmic structures. Voronca, an enthusiast for the spectacle of modernity, appears also as anguished subject in search of both self and a community of likeminded, solidary souls. These long poems bring to light an evolution of his poetic discourse: there is now more articulation and less indebtedness to the "constructivist" program; the "engineer" gradually steps back from his "drawing board" where he had been using a ruler and a pair of compasses to draw images a bit too coldly geometrical.

\section{From Integralism to Surrealism}

The same evolution can also be noted in Voronca's observations on poetry written during the subsequent years, when a new avant-garde journal appeared on the scene: with Saşa Pană as editor, unu would have a relatively long run of fifty issues between April 1928 and December 1932. Although the short "Manifesto" published in the first issue of the magazine mentions "76 h. p.," suggesting a continued program in the vein of Integral, (mentioned, in telegraphic fashion, are names such as: "marinetti / breton / vinea / tzara / ribemont-dessaignes / arghezi / brîncuş" all greeted with "Hoooray"), and despite the text's abrupt ending which incites to innovation in the familiar syncopated style ("Combină verb / abcdefghijklmnopqrstuvzxyz / = artă ritm viteză . . granite / guttenberg reînvii" 'Combine verb / abcdefghijklmnopqrstuvzxyz / = art rhythm speed ...g g a n i t e / gutenberg resurrects'), the journal unu starts to show surrealist tendencies very early on. Not that this is stated openly, since merely some similarities are pointed out between Breton's movement and the work of the unu group, while asserting that the latter is not a "literary movement" but rather a "state of mind." The group's militants (Voronca, Brauner, Gheorghe Dinu-Roll, Geo Bogza, among others, but also Tristan Tzara, Benjmin Fondane, and Claude Sernet, who contributed in French) were in part members of earlier groups, lending a certain cohesion to unu. But at the same time their presence testified to a rapid, almost feverish evolution from one artistic program to another, in an effort to keep up-todate and synchronize with everything new arriving on the scene in the arts and literature. In this milieu, it is still Voronca who stands out as the main reference point and model, since his companions, with the exception of the younger Geo Bogza, follow a model of poetry that is closest to the "imagism" of the author of 
Ulise, even when they are writing programmatic texts or reviewing books by their peers. As for Bogza, who had a remarkably strong personality and poetic voice, he would stand apart with his "journalistic" style stripped of imagery, seeking to provide an unmediated grasp of "primordial" lived experience and to render an attitude of "creative exasperation" embodied in a "poetry of insults" (such as "Poemul invectivă") defying "bourgeois" conventions and hypocrisy.

Ilarie Voronca's role in the constitution of this new avant-garde circle is extremely important. In the pages of $u n u$, he published a number of critical essays, reflections on poetry, as well as poems from his recent collections. In September 1930 he published the polemical text that marked the break with the constructivism of Contimporanul, under the suggestive title "Coliva lui Moş Vinea" (The Funeral Feast of Uncle Vinea), signed "uNu." It is a gesture that says much about the poet's turn toward surrealism, which he had rejected just a few years earlier.

Să se ştie odată pentru totdeauna: CONTIMPORANUL nu are nimic comun cu entuziasmul şi tinerețea noastră, cu arta şi cu spiritul pe care singuri le reprezentăm aici la această oră.

Şi mai avem de adăugat: chiar dacă n-ar fi dubioasa flagrantă atitudine a Contimporanului, mişcarea pe care ar voi s-o reprezinte, "constructivismul," şi în care s-a fixat de la apariția lui, e cu totul străină de vederile actuale ale lui "Unu," care îşi revendică o conduită cu totul ruptă de realitate, cu totul în afara utilitarismului Constructivist rezolvat în arhitectură, şi care clatină în havuzurile visului apele unor viziuni desfăcute de orice probleme şi continuităţi situate dincolo de poem şi de semitrezie.

Let it be known once and for all: CONTIMPORANUL has nothing whatsoever in common with our enthusiasm and youth, or with the art and the spirit which we alone represent currently.

And to this we will add: even if it weren't for the dubious, flagrant attitude of Contimporanul, "constructivism" itself, the movement it supposedly wishes to represent, and into which it had fixated itself since its inception, is totally alien to the current views of "Unu," which claims an attitude of total break with reality, totally outside the Constructivist utilitarianism that found its venue in architecture. Unu is now undulating in the fountains of dreams the ripples of visions detached from any concerns or any continuity beyond the poem and the half-waking state.

Clearly, the terminology announcing this split is based in surrealist vocabulary and Voronca will indeed continue moving in this direction. He will replace the old definition of the poetic image as an "abstract invention" with one more in tune with this new group's spirit, while still retaining the schema of the image as "flash of lightning" derived from the tense association of either very distant or closely 
related elements. But for the plastic precision of the image he will substitute "revelaţia de o clipă numai, a invizibilului, neprevăzutul" 'the revelation, in a flash, of the invisible, the unpredictable" and "acele laturi revelate de întâmplare ... scrisul închinat unei viziuni" (A doua lumină passim) 'those facets revealed by chance . . . the writing devoted to a vision,' the poem as "risc, aventură totală," "succesiune de hazarduri" 'risk taking, total adventure . . succession of chance events.' The style Voronca called "alunecarea într-o cale lactee de imagini" 'gliding into a Milky Way of images' will define the poetry of the unu group, with the exception of Geo Bogza, as mentioned above ("Între mine şi mine").

In Voronca's writings during this time of membership in the unu group, it is difficult to separate the purely reflective meditation about poetry from the "prose poem" genre - so much does his militant thinking converge with and communicate his engagement in the service of poetry without boundaries. The sentimental, sometimes exalted, delicate, and fragile Voronca, of whom Lovinescu painted the picture quoted above, reveals himself in each page of these essaypoems, which are infused with the pathos of the unusual confession. A review of a book by his friend Stephan Roll contains almost no critical reading; rather, it appears to be a pretext, a platform for arduous professions of love for poetry and of a passion for writing: "Poemul e un miracol; e o izbucnire de scuturi prin cavalcadele furtunii. E revelaţia de o clipă numai, a invizibilului. Poemul e o pătrundere de iod prin mădulare, un al doilea auz deschis la toate zvonurile văzduhului. Gângăveala unui copil ceresc nedesluşită alfabetului atâtor registre de comerț şi dicționare" "The poem is a miracle; it is an outburst of shields through the storm's cavalcade. It is the revelation, in a flash, of the invisible. The poem is the penetration of iodine into the limbs, a second hearing attuned to the rumors of the heavens. The babbling of a celestial child, undecipherable according to the alphabet of so many accounting books and dictionaries.' Similarly, the following passage that offers, to borrow Breton's terms, a little "discours sur le peu de réalité" 'discourse on the paucity of reality," achieves liturgical tonalities: "Sensul lumii reale ne scapă. Dar lumea reală e prea puțină pentru posibilităţile de creație şi de invenţie din noi. În fulgerul unei imagini, toate fântânile universului reînnoite. . . . Singura certitudine: poemul. Singura cuminecătură: poemul. Luați, mâncaţi, acesta este trupul şi sângele nostru: poemul" ("'Poeme în aer liber'”) 'The sense of the real world escapes us. But the real world does not suffice for the creative and inventive possibilities in us. In the flash of an image, all sources of the universe [are] renewed. Our only certainty: the poem. Our only communion: the poem. Take, eat; this is our body and our blood: the poem.' The mold of the image remains the same, but the content changes radically: it will no longer be a spark sprung from the clashing of two geometric entities; more vague and imponderable matters are sought. We could measure the distance from the constructivist perspective in the already quoted "Între mine şi mine"- published originally in unu, then reprinted in the 1930 collection - on the same theme: "Devierea gândului prin cuvânt, alunecarea într-o cale lactee de imagini, iată ceea ce constituie însăşi 
unealta de azur a meşteşugului de a scrie. Căci, judecând drept, e cu adevărat lamentabil mormanul de hârţoage sterpe şi fudule pe care le-au născut eforturile cugetării în precizie, sau inutila strădanie a unei gândiri cu metodă" "Thought drifting through word, gliding into a Milky Way of images, these are the azure tools of the trade of writing. Because, in all fairness, they are truly lamentable, the sterile and vainglorious heaps of paper produced by efforts at precise reflection, or futile striving toward methodical thinking.' It is in this context that Voronca eulogizes dreams as liberating agents which offer freedom from inherited conventions: "Dar în curând, peste toate rădăcinile smulse, apele visului vor veni în puhoaie albe, şi înfăţişările cu legi şi formule vor fi duse în prăpastie ca turmele păstorului surprins de furtună” ‘But soon, the flowing waters of dreams will come in white torrents, washing over torn roots, and the legal appearances with rules and laws will be washed away, like the herds of the shepherd surprised by the storm.' The poet now sounds like a Romantic, invoking 'the WHOLE,' seeing himself perched on "stânca aridă a visului" 'the barren rock of the dream' from which he looks with disdain upon the bourgeois who is "fără vise, ca în trezie" 'without dreams, as if always awake.' In a different piece, titled "Radiografie," Voronca states that "Scrisul presupune o elevatie, o transfigurare, o trecere 'dincolo', pe care, cu un limbaj devenit insuficient, va trebui să o numesc inspirație" 'Writing presupposes an elevation, a transfiguration, a passing into a 'beyond,' which, in a terminology become inadequate, I will have to call "inspiration."' These are only a few of the formulas demonstrating the substantial change that occurred in Voronca's view of poetry.

In the pages of $u n u$, as we have already noted, Voronca primarily published, serially, from his new books starting with Ulise and including Zodiac. He also published from the poems that would become Plante si animale (Plants and Animals, 1929) with intentionally naïve illustrations by Brancusi that matched perfectly Voronca's "Franciscan" vision, a vision that, however, did not exclude maintaining his "neo-baroque" composition technique, albeit simplified. In this context, a surprising collection of poems is Incantaţii (Incantations, 1931), which caused scandal inside the group, having been published by Cultura Naţională, a publishing house considered all too "official." His friend and comrade, Gheorghe Dinu, who had eulogized him on the occasion of each new publication over the years, greeted the volume with ardent criticism, charging that the author had submitted to the hierarchy dictated by the cultural establishment. Moreover, Voronca was also blamed for his attempts at being inducted into the Romanian Writers' Association. There were, then, serious motives for his exclusion from the unu group in November 1931, one other reason being - as ironically pointed out by Stephan Roll in his review of the volume -Voronca's use of the alexandrine rhyme, along with other traditional poetic forms. This volume was not, in reality, the poet's first experiment in the traditional rhythmic vein, since the poem Colomba (also the name of the poet's wife, to whom he would dedicate almost all his books) that appeared in 1927 had already demonstrated detailed attention to the prosody 
and musical effects of "classical" verse and stanzas, deployed as a dam against the always abundant surge of images. As if to counterbalance matters slightly, Voronca would include ten poems from his "constructivist" period in another, minuscule collection, published under the title Invitaţie la bal ('Invitation to a Ball'), borrowed from a representative poem in the volume.

On the other hand, the work that would show most clearly his adherence to the surrealist vision and sensibility would be Patmos from 1933. Its symbolic protagonist is "The Phantom Isle," a dream-like, hallucinatory projection of a state of anguish and extreme solitude, reflecting perhaps the poet's state of mind at the difficult time of rupture with his avant-garde comrades. Alongside Ulise, this second long poem is Voronca's most significant work, creating visions in which the anxiety of the marginalized being is enmeshed in luminous reveries about a time of happiness, with all humanity united in universal love. Interestingly, free verse and poetic prose alternate in this piece with sonnets. This indicates that the poet continues to situate himself at a kind of threshold between the avant-garde's revolutionary spirit and the difficult struggle to find an existential and creative balance. The prose poems collected in Act de prezenţă (Being Present) published in 1932 are steeped in the same ambiguous atmosphere that reflects a difficult period in the author's life, following his dismissal from his position in the press corps of the Ministry of Foreign Affairs on grounds of his racial origins. From a stylistic point of view, Voronca is pursuing his "poemotherapy" (the title of a poem in this volume), since the "prose writer" remains attached to the baroque and mannerist style of writing that he had adopted in his earlier "billionaire of images" stage.

\section{Final Stages of Evolution}

After his move to Paris in 1933 - Paris being the city he had frequently visited in the past and where he had even worked as an insurance agent while earning his doctorate in law - Voronca turned to French definitively. He also had three of his volumes translated into French: Ulise appeared in 1933 with the French title Ulysse dans la cité (Ulysses in the City); Petre Schlemihl became Poèmes parmi les hommes (Poems Among Men) and appeared in 1934 along with Patmos. Between 1934 and 1937 Voronca did, however, send articles in Romanian to the daily Adevărul (The Truth) on various cultural topics from either the French or Romanian contexts. These pieces are stylistically closest to his prose poems, exhibiting a departure from the avant-garde experimental techniques upon which he now looked with a certain distance: the poet seems "wiser" now, writing, for example, in "praise of old age." Interesting in this respect is the fact that Voronca had left behind in Romania a manuscript titled Quatorze Sonnets (Fourteen Sonnets), consisting of poems of great formal intensity, reminiscent in some respects of Ion Barbu's vision and technique - Barbu being the "hermetic" author of Joc secund (Second Game, 1930). If we recall his use of the traditional alexandrine verse in the 1931 volume, and the controversy it produced at $u n u$, given also its "official" publication venue, 
we can then speculate on the motivation behind these later poetic tendencies in the following manner: On the one hand, we can see here a desire to be integrated into the less "revolutionary" contemporary literary circles of Romania at the time of his application to the Romanian Writers' Association. On the other hand, however, this evolution toward a more "classicist" form can also be attributed to the "aging" of the avant-garde itself, noted the world over, with some former avant-gardists becoming even academicians. We must also stress the fact that the poetic discourse of Voronca's later volumes, such as Petre Schlemihl from 1932, tends to become much more simple and direct and far less "imagery-driven" than that of his earlier work. Thus, when it appeared in France, the latter collection bore the revealing new title Poèmes parmi les hommes, serving in a sense as the opening of Voronca's French literary career.

From here onward his poetry is that of one who confesses, quite contrary to his earlier avant-garde experiments, "Aujourd'hui / Je ne trouverais plus aucune joie à réunir des mots étranges // Et même les images les plus surprenantes, je m'en souviens, mais à quoi bon ?" 'Today / I would no longer find pleasure in joining strange words together // And even the most startling images, which I do remember, what are they good for?' From now on, his poetry becomes "Poésie commune" 'common poetry,' as the title of a 1935 volume would put it. In effect, his lyrical discourse is seeking the most direct expression of a generous message addressed, beyond anxiety, to "the masses of the future" proclaiming, in the title of a 1936 book, that "la joie est pour l'homme" 'joy is for mankind.' But he who during his avant-garde period had declared that he detected anxiety in the poets' eyes had not managed to overcome that anxiety in himself, taking his own life shortly after the war.

Thus, Ilarie Voronca as militant avant-garde poet existed only in the Romanian cultural context, during a period in his life when he was enthusiastically engaged with experiments in "extreme" modernity, fighting against all "conventions," whether stereotypes in poetic language or the conformism of the "bourgeois" spirit. His vision of the "new poetry" places him among the innovators of poetic syntax, using a "simultaneist" style that led to a particular dynamic in poetic discourse in tune with the "rhythm of the era." This energy is transmitted, at first, via the reverberations of the "industrial activist phase" invoked by constructivism and also fueled by the verve of futurism; later it is found in a technique close to the "pure psychological automatism" of the surrealists, focused on the depths of inner life. If Romanian critics could justly criticize Voronca for the excess of randomness that made its way into the poet's imagery, obscuring any coherent world view, it is nonetheless true that several of his volumes, most notably Ulise and Patmos, are to be counted among the most representative works of modern Romanian poetry. 


\section{Works Cited}

Brauner, Victor. [Interview with Ionel Jianu]. Rampa (31 March 1928). Print.

Brauner, Victor, and Ilarie Voronca. "Pictopoetry." Between Worlds: A Sourcebook of Central European Avant-gardes, 1910-1930. Ed. Timothy O. Benson and Éva Forgács. Los Angeles: Los Angeles County Museum of Art; Cambridge: MIT $\mathrm{P}$, 2002. 538. Print.

—. "Pictopoezie." 75 HP (1924): n. pag. Print.

Cosma, Mihail. “De la futurism la integralism.” Integral 6-7 (Oct. 1925): 8-9. Print. Dinu, Gheorghe. "Şacalul acestui colibri." Unu 41 (Nov. 1931): n. pag. Print.

Lovinescu, Eugen. Memorii. Vol. 2. Craiova: Scrisul Românesc, 1932. Print.

Ribemont-Dessaignes, Georges. “Au Public.” Littérature 13 (May 1920): 18. Print. Tzara, Tristan. "Dada Manifesto 1918." Seven Dada Manifestos and Lampisteries.

Trans. Barbara Wright. London: Calder; New York, Riverrun P, 1981. 3-13. Print.

—. "Manifeste Dada 1918." CEuvres complètes. Ed. Henri Béhar. Vol. 1. Paris: Flammarion, 1975. 359-67. Print.

Voronca, Ilarie. “1924.” 75 HP (1924): n. pag. Print. As Alex. Cernat. . "Aviogramă." 75 HP (1924): n. pag. Print.

. "Aviogramă." Trans. Monica Voi[cu]lescu. Between Worlds: A Sourcebook

of Central European Avant-gardes, 1910-1930. Ed. Timothy O. Benson and Éva Forgács. Los Angeles: Los Angeles County Museum of Art; Cambridge: MIT P, 2002. 535-37. Print.

—. "Cicatrizări: Poezia nouă." Integral 4 (June 1925): 3-4. Print.

—. "Coliva lui Moş Vinea.” Unu 29 (Sept. 1930): n. pag. Print.

-. A doua lumină. Bucharest: Unu, 1930. Print.

—_. "Les foules de l'Avenir." La Poésie commune. Paris: G.L.M., 1936. N. pag. Print.

—. "Glasuri." Punct 8 (9 Jan. 1925). Print.

—. "Gramatică." Punct 6-7 (3 Jan. 1925): n. pag. Print.

—. "Între mine şi mine." Unu 19 (Nov. 1929): n. pag. Print.

_. "'Poeme în aer liber' de Stephan Roll.” Unu 13 (May 1929): n. pag. Print.

—. "Radiografie." Unu 25 (May 1930): n. pag. Print.

—. Restriști. [Bucharest]: "Rahova" Arte Grafice, 1923. Print.

—. "Tudor Arghezi - fierar al cuvântului." Integral 3 (May 1925): 6. Print.

- "Untitled Statement." Trans. Monica Voi[cu]lescu. Between Worlds: A

Sourcebook of Central European Avant-gardes, 1910-1930. Ed. Timothy O. Benson and Éva Forgács. Los Angeles: Los Angeles County Museum of Art; Cambridge: MIT P, 2002. 537. Print. 